\title{
ANALYSIS OF SEASONAL AND ANNUAL TRENDS OF SULPHUR DIOXIDE AS AIR POLLUTANT IN BAREILLY CITY
}

\author{
Sachin Agarwal ${ }^{1}$ and Boyina Rupini ${ }^{2}$
}

${ }^{1}$ Environmental Sciences, IGNOU, New Delhi

${ }^{2}$ SOITS, IGNOU, New Delhi

\begin{abstract}
According to a report published by Green Peace (2018), Bareilly city has been reported as one of the most seven polluted cities. Bareilly city do not have too much of industrialization but poor environmental management by the citizens and administration worsen the air quality during Diwali festival. Air monitoring of gaseous pollutant (sulphur dioxide) was done at Bareilly city as per CPCB guidelines from three monitoring stations (A, B and C) for a period of two years (2019-2020). During pre-monsoon season of 2019 all station reported $\mathrm{SO}_{2}$ values below the specified limits of $60 \mu \mathrm{g} / \mathrm{m}^{3}$ but station A reported values on the higher side. When lockdown was imposed in March 2020 due to the outbreak of novel corona virus in India and there was significant cut down in $\mathrm{SO}_{2}$. While conducting the two-way ANOVA test for $\mathrm{SO}_{2}$ during both pre-monsoon and post-monsoon seasons from three stations at Bareilly in 2019, it was found that $F>F_{\text {crit. }}$ and $p$-value $<0.05$. This paper focuses on the monitoring, analysis and interpretation of $\mathrm{SO}_{2}$ at Bareilly city.
\end{abstract}

\section{Keywords}

Bareilly, vehicular emissions, PM2.5, pre-monsoon, lockdown, coronavirus

\section{INTRODUCTION}

Air pollution isn't restricted to a state, country, region or continent, it could have significant effect on global climate and weather, acid rain issue since the 1970s is a well-aware problem for the world. Formation of acid rain takes place when $\mathrm{SO}_{2}$ and oxides of nitrogen from the burning of excessive fossil fuels combine with the vapour in the atmosphere, forming mist of $\mathrm{H}_{2} \mathrm{SO}_{4}$ and $\mathrm{HNO}_{3}$ that causes damage to water, forest, and soil resources. With the rise in the fossil fuel consumption, $\mathrm{CO}_{2}$ levels in the atmosphere have increased steadily since 1900 , and the rate continues to be on the rise. It has been predicted that if $\mathrm{CO}_{2}$ levels are not reduced, average global air temperatures may rise another 4 ${ }^{\circ} \mathrm{C}\left(7.2^{\circ} \mathrm{F}\right)$ by the end of the 21 st century. This may lead to the melting of the polar ice caps, elevation in the level of sea water, and flooding of the coastal areas globally. Alterations in precipitation patterns caused by climate changes and global warming could cause adverse effects on agriculture and forest ecosystems, and higher temperatures and humidity might increase the incidence of disease in humans and animals in some parts of the earth. Globally we see that in recent decades the death rates from total air pollution have declined: since 1990 the number of deaths per 100,000 people have nearly halved. But, as we see from the breakdown, this decline has been primarily driven by improvements in indoor air pollution. (source, IHME, Global Burden of disease). In a report of WHO, 2018 it has been reported that due to both indoor and outdoor air pollution around seven million people die each year. The three biggest killers attributable to air pollution are stroke (2.2 million deaths), cardiac disease (2.0 million) and lung disease and cancer (1.7 million deaths).Ambient (outdoor) air pollution accounts for: 25 per cent of all deaths and disease from lung cancer, 17 per cent of all deaths and disease from acute lower respiratory infection, 16 per cent of all deaths from stroke 15 per cent of all deaths and disease from ischaemic cardiovascular disease and 8 per 
cent of all deaths and disease from chronic obstructive pulmonary disease .Air pollution doesn't just kill, however. It also contributes to other illnesses, hampers development and causes neurological dis-orderness. One study found that ambient PM2.5 contributed to more than three million cas es of diabetes in 2016.Recent research from the United Nations Children's Fund (UNICEF) shows that inhaling in particulate air pollution can damage brain tissue and undermine cognitive development in young children - with lifelong implications. In India air pollution is very alarming in the currents scenario. According to (WHO -2018) and the fourth edition of State of India's Environment (SoE) released on World Environment Day, 5th June 2019 air pollution cause a death toll of an average of around 80 out of every one lakh children in India before they turn five. Urban air quality in megacities getting deteriorated day by day due to increase in industrialization and urbanization [1, 2].Population pressure can't be ruled out for a few reason. To satisfy out demand of population explosion natural resources are being harvested and transported. The rapid urban grow th is also associated with transportation sector and road networks which supports various vehicular movements on roads [3]. Air pollution in India is predominantly caused from three sources namely vehicles [4], industrial and domestic sources. It was reported that air pollutants like NOx and PM concentration (approximately $17 \%$ and $28 \%$ of total ) from vehicular emissions are contributed to the air pollution which was almost equal to the cumulative sources of industry, power plants and domestic sectors in Delhi, India [5]. However, over the last twenty years petrol and diesel consumption have hiked by $400 \%$ and $300 \%$, respectively, which was mainly because of rise of vehicular numbers, DG sets, industries and waste incinerators $[6,7]$. The heavy traffic , thickly populated areas, jams, poor driving patterns ,improper town planning and congested and encroached roads have severe impact on the environment in urban areas [1, 8, 9, 10,11].

Vehicular emissions is associated with a number of chronic and acute health effects [12,13]. Various studies proved that health issues such as cancers, heart attacks and asthma are associated with $\mathrm{NOx}, \mathrm{SO}_{2}$ and $\mathrm{PM}$ emissions from vehicular exhaust [14, 15]. In urban areas, air pollution is affected mainly due to construction of buildings, traffic composition and meteorological conditions [16]. Air quality models and impact because of pollutant concentration assessment studies provide a tool to better understand the implications of pollutant emissions which could help us to decide, control and manage the environmental pollutions [17]. Air pollutant dispersion modeling has been accomplished with the aid of Gaussian Dispersion Plume models that, accounted for the spatial and temporal dispersion characteristics of various pollutants. However, line source models are generally used to assess the effects of roadway emissions and dispersion of the pollutants $[18,19]$. Traffic estimation studies can either be done by on-site traffic counting (manually or installing CCTV camera or counter devices) [20, 21, 22], or derived from travel demand and traffic simulation models [23, 24, 25]. Emissions are often estimated considering average link speeds and average emission factors [20, 22, 23, 25] or realtime link drive-cycles [24]. Airborne particulate matter (PM) is a type of a colloidal solution composed of small droplets of liquid, dry solid fragments, and solid cores with liquid coatings. PM particles are not a single pollutant, instead it is a mixture of different chemical species. Therefore, PM2.5 comprises a portion of PM10. The primary source of Particulate matter is from anthropogenic activities such as burning of fossil fuel, vehicular emissions, road dust suspensions, wear out of brakes and tyres, ash from industries as well as incomplete construction work. Exhaust traffic related particles have been identified as a major contributor to ambient PM. Vehicular emissions are one of the major sources of outdoor air pollution in major cities of India. The number of vehicles on road has increased non-linearly over the past two decades has resulted in high levels of air pollution. In most of the major cities/towns there has been uncontrolled growth of vehicle population. High vehicle density in Indian urban centers results in air pollution buildup near the roadways and at traffic intersections. Older vehicles are predominant in vehicle vintage. Older vehicles release more air pollutants hence vehicles older than 15 years of registration are now been phased out and cannot move on roads in Delhi. But, in small cities still old vehicles are being operated on roads without a stringent check. Inadequate inspection and maintenance facilities result in high emission of air pollutants from vehicles. In order to reduce the emission of particulate matter and gaseous pollutants, regular inspection and maintenance of vehicles should be done. Also, vehicles in India easily get Pollution Under Control certificate. According to the Society of Indian Automobile Manufacturer (SIAM) [Table 1]automobile sale trend was studied over a period of five years as shown in the table below:

Table1: Automobile Domestic Sale Trends for the period of six years 2014 to 2020 .

\begin{tabular}{|l|c|c|c|c|c|c|}
\hline Category & $\mathbf{2 0 1 4 - 1 5}$ & $\mathbf{2 0 1 5}-\mathbf{1 6}$ & $\mathbf{2 0 1 6}-\mathbf{1 7}$ & $\mathbf{2 0 1 7 - 1 8}$ & $\mathbf{2 0 1 8}-\mathbf{1 9}$ & $\mathbf{2 0 1 9}-\mathbf{2 0}$ \\
\hline Passenger Vehicles & $2,601,236$ & $2,789,208$ & $3,047,582$ & $3,288,581$ & $3,377,389$ & $2,773,575$ \\
\hline Commercial Vehicles & 614,948 & 685,704 & 714,082 & 856,916 & $10,07,311$ & 717,688 \\
\hline Three Wheelers & 532,626 & 538,208 & 511,879 & 635,698 & $7,01,005$ & 636,569 \\
\hline Two Wheelers & $15,975,561$ & $16,455,851$ & $17,589,738$ & $20,200,117$ & $21,179,847$ & $17,417,616$ \\
\hline Quadricycle\# & & 0 & 0 & 0 & 627 & 942 \\
\hline Grand Total & $19,724,371$ & $20,468,971$ & $21,863,281$ & $24,981,312$ & $26,266,179$ & $21,546,390$ \\
\hline
\end{tabular}


Day by day the air quality which we are inhaling is being detoriated and getting even worsen. It has been found and reported that around ten million people from India[31] lose their lives due to air pollution. Around 30\% of cardiac patient are affected due to air pollution[32]. School going children and new born babies are suffering from emphysema. Also senior citizen are suffering from breathlessness due to emission of pollutant. Hence a serious monitoring, analysis and remedial steps need to be taken in this regards. CPCB and also media reported that Bareilly [Figure 1] was thickly polluted and in UP the third most polluted city.

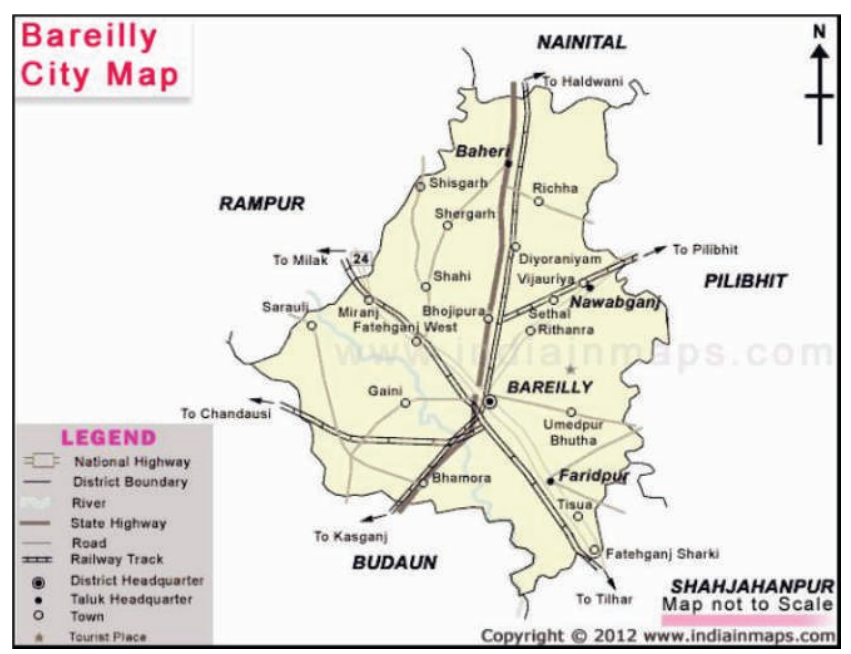

Figure 1: Bareilly Map (source : www.indiamaps.com)

There are more than 30 fuel pumps in Bareilly city [Figure 2] and due to large population there is huge consumption of fuel in the entire city.

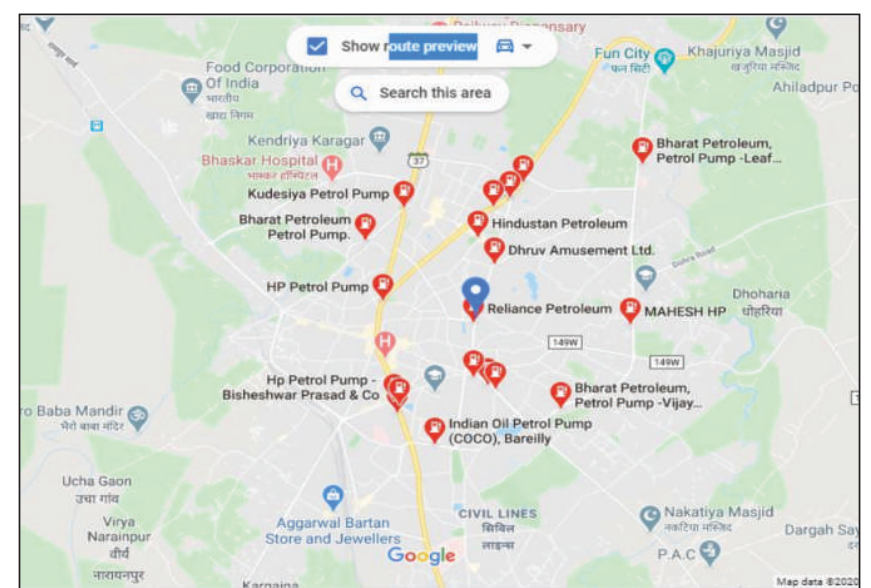

Figure 4: Fuel Station at Bareilly. (Image taken from Google Maps)

\section{Material and Methods to measure $\mathrm{SO}_{2}$ in air}

\section{Modified West \& Gaeke Method for the Measurement of} Air Pollution: Sulphur dioxide.

In this procedure, Sulphur dioxide from aerial mixture was made to absorb in a solution of potassium tetrachloromercurate (TCM) with subsequent formation of a dichloro-sulphitomercurate complex, which resists oxidation by the oxygen in the air. This resultant complex is highly stable to strong oxidants like ozone and oxides of nitrogen hence the absorber solution may be stored for some time prior to analysis. The reaction between the dichlorosulphitomercurate complex and para-rosaniline and formaldehyde resulted in pararosaniline methyl sulphonic acid. The absorbance of the solution is measured by means of a suitable spectrophotometer.

\begin{tabular}{|l|c|c|c|}
\hline Pollutant & Time Weighted Average & \multicolumn{2}{|c|}{ Time Weighted Average } \\
\cline { 3 - 4 } & & $\begin{array}{l}\text { Industrial, Residential, } \\
\text { Rural and other Areas }\end{array}$ & $\begin{array}{l}\text { Ecologically Sensitive } \\
\text { Area (Notified by } \\
\text { Central Government) }\end{array}$ \\
\hline $\begin{array}{l}\text { Sulphur Dioxide }\left(\mathrm{So}_{2}\right), \\
\mu \mathrm{g} / \mathrm{m}^{3}\end{array}$ & Annual* & 50 \\
\hline \multicolumn{2}{|c|}{24 Hours ** } & 20 \\
\hline $\begin{array}{l}* \text { Annual Arithmetic mean of minimum } 104 \text { measurements in a year, at a particular site, taken twice a week 24 hourly at } \\
\text { uniform intervals. } \\
* * 24 \text { hourly or } 8 \text { hourly or } 1 \text { hourly monitored values, as applicable, shall be complied with 98\% of the time in a year. 2\% of } \\
\text { the time, they may exceed the limits but not on two consecutive days of monitoring. }\end{array}$ \\
\hline
\end{tabular}

Concentration of sulphite solution:

$$
\mathrm{C}=\frac{(\mathrm{V} 1-\mathrm{V} 2) \times \mathrm{N} \times \mathrm{K}}{\mathrm{V}}
$$

Where,

$\mathrm{C}=\mathrm{SO}_{2}$ concentration in $\mathrm{mg} / \mathrm{ml}$

$\mathrm{V} 1$ = Volume of thiosulfate for blank, ml

$\mathrm{V} 2$ = Volume of thiosulfate for sample, $\mathrm{ml}$

$\mathrm{N}=$ Normality of thiosulfate

$\mathrm{K}=32000$ (Milliequivalent weight $\mathrm{SO}_{2} / \mu \mathrm{g}$ )

$\mathrm{V}=$ Volume of standard sulphite solution, $\mathrm{ml}$
$\mathrm{C}\left(\mathrm{SO}_{2} \mu \mathrm{g} / \mathrm{m}^{3}\right)=(\mathrm{As}-\mathrm{Ab}) \times \mathrm{CF} \times \mathrm{Vs} / \mathrm{Va} \times \mathrm{Vt}$

Where,

C $\mathrm{SO}_{2}=$ Concentration of Nitrogen dioxide, $\mu \mathrm{g} / \mathrm{m}^{3}$

As = Absorbance of sample

$\mathrm{Ab}=$ Absorbance of reagent blank

$\mathrm{CF}=$ Calibration factor

$\mathrm{Va}=$ Volume of air sampled, $\mathrm{m}^{3}$

$\mathrm{Vs}=$ Volume of sample, $\mathrm{ml}$

$\mathrm{Vt}=$ Volume of aliquot taken for analysis, $\mathrm{ml}$ 
This paper focuses on the data organization of gaseous air pollutant $\mathrm{SO}_{2}$ from three monitoring stations of Bareilly district. The air monitoring was carried out at the following three stations at Bareilly district. The field data obtained was recorded and analysed in the laboratory. All data obtained during the year 2019 during field research was organized, analysed, interpreted and represented in the form graphs and tables for better analysis and evaluation. Following are the monitoring stations /location [Figure 3] from where the air pollutants have been sampled for analysis.

\section{Results and Discussions}

The collection of data was done as per the CPCB guideline and methods were followed as discussed in chapter three. Table represents monthly average concentrations of $\mathrm{SO}_{2}$ pollutants in $\mu \mathrm{g} / \mathrm{m}^{3}$ from three stations $\mathrm{A}, \mathrm{B}$ and $\mathrm{C}$ respectively. The first six months of the year i.e. January 2019 to June 2019 are studied as Pre-monsoon season and from July 2019 to December 2019 are studied under Post Monsoon season.

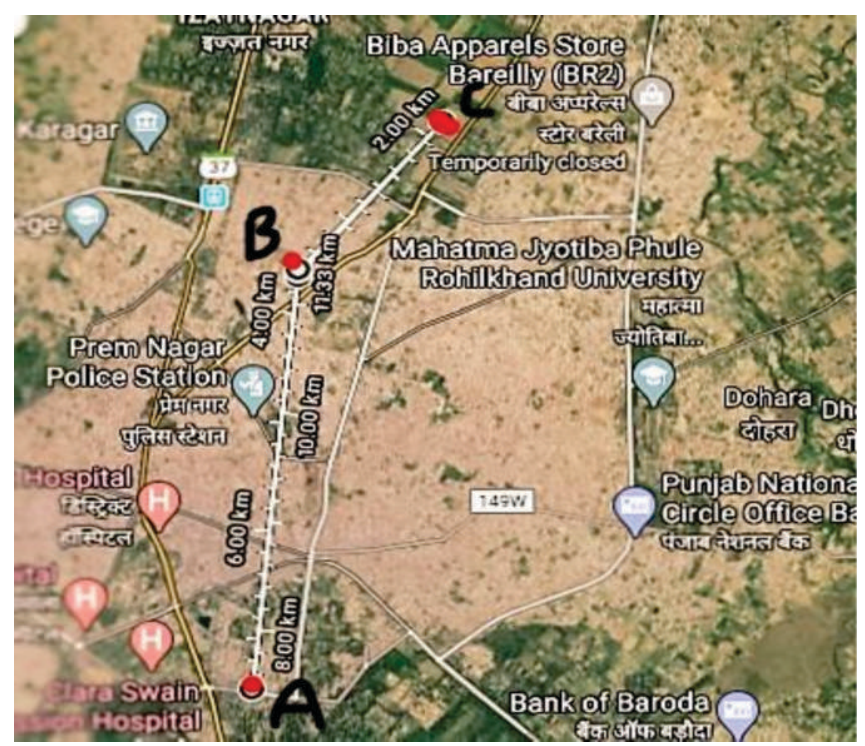

Figure 3: Station A : Coco Pump, Civil lines Bareilly (28.8348 N/79.424 E),

Station B: DD Puram, Bareilly, 28.831N/79.428E, Station C: IVRI Bareilly 28.393N/79.428E

Table 2: $\mathrm{SO}_{2}$ data during Pre-monsoon and Post monsoon in 2019 from three stations.

\begin{tabular}{|l|c|c|c|c|}
\hline Seasons & Months & $\begin{array}{c}\text { STATION A } \\
\mathbf{2 8 . 8 3 4 8} \mathbf{~ N / 7 9 . 4 2 4 ~ E ~}\end{array}$ & $\begin{array}{c}\text { STATION B } \\
\mathbf{2 8 . 8 3 1 N / 7 9 . 4 2 8 E}\end{array}$ & $\begin{array}{c}\text { STATION C } \\
\mathbf{2 8 . 3 9 3 N} / 79.428 E\end{array}$ \\
\hline \multirow{4}{*}{ PREMONSOON } & January & 32.6 & 19 & 11.34 \\
\cline { 2 - 5 } & February & 18.45 & 18 & 12.01 \\
\cline { 2 - 5 } & March & 27.25 & 19 & 10.31 \\
\cline { 2 - 5 } & April & 12.05 & 13 & 11.04 \\
\cline { 2 - 5 } & May & 32.25 & 21 & 10.01 \\
\cline { 2 - 5 } & June & 33.69 & 23 & 9.17 \\
\cline { 2 - 5 } & July & 34.13 & 19 & 8.89 \\
\cline { 2 - 5 } & August & 29.13 & 18 & 9.32 \\
\cline { 2 - 5 } & September & 32.57 & 24 & 10.62 \\
\cline { 2 - 5 } & October & 46.6 & 23 & 13.31 \\
\cline { 2 - 5 } & November & 60.78 & 43 & 29.61 \\
\cline { 2 - 5 } & December & 57.61 & 37 & 20.05 \\
\hline
\end{tabular}

\section{PREMONSOON TRENDS OF $\mathrm{SO}_{2}$}

During the Pre-monsoon season, as can be seen from the following figure that all stations reported $\mathrm{SO}_{2}$ concentration are below the maximum permissible limit of $60 \mu \mathrm{g} / \mathrm{m}^{3}$ according to NAAQS. Station A, located on the highway, is considered to be heavy traffic site, where as station $\mathrm{C}$ being a residential site was considered to be control site or low traffic site. Station B is commercial cum residential site. The green worm in the following figure corresponds to station $\mathrm{C}$ which lies always below the curves corresponding to station $\mathrm{A}$ and station B during the entire pre-monsoon season. No regular trend is observed during the pre-monsoon season but the values remained below the maximum allowable limits.

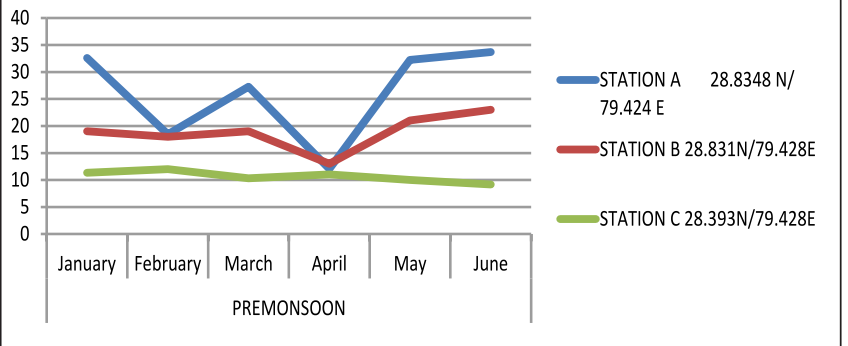

Figure 4: Pre-monsoon trends of $\mathrm{SO}_{2}$ during 2019.

Post-monsoon comparative data for $\mathrm{SO}_{2}$

During the post- monsoon season all station show an increasing trends till the month of November 2019 in the values of $\mathrm{SO}_{2}$ concentration. As expected, the low vehicular site, Station $\mathrm{C}$, reported the least value of $\mathrm{SO}_{2}$ concentration during the entire post monsoon season. 


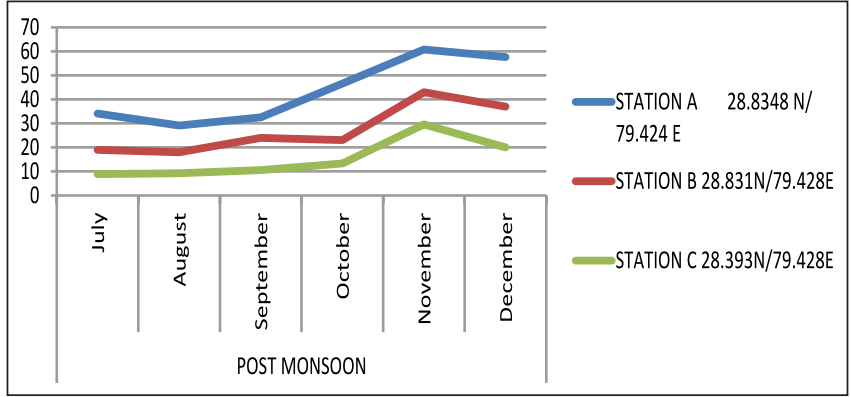

Figure 5: Pre-monsoon trends of $\mathrm{SO}_{2}$ during 2019.

ANNUAL TRENDS (Pre and Post Monsoon)

OF $\mathrm{So}_{2}$ FOR THE YEAR 2019

Bareilly city do not have too much of industries emitting gaseous pollutants. The only major source of gaseous pollutant in the city is vehicular emissions, which can be verified from the annual trend analysis of $\mathrm{SO}_{2}$ levels at the three air monitoring sites. Station A showed relatively large values of $\mathrm{SO}_{2}$ as it is located on highway and is a heavy vehicular site. During the entire 2019 all stations reached their individual peak value only the month of November 2019 which is possibly due to the emission from fire crackers burned during Diwali festival.

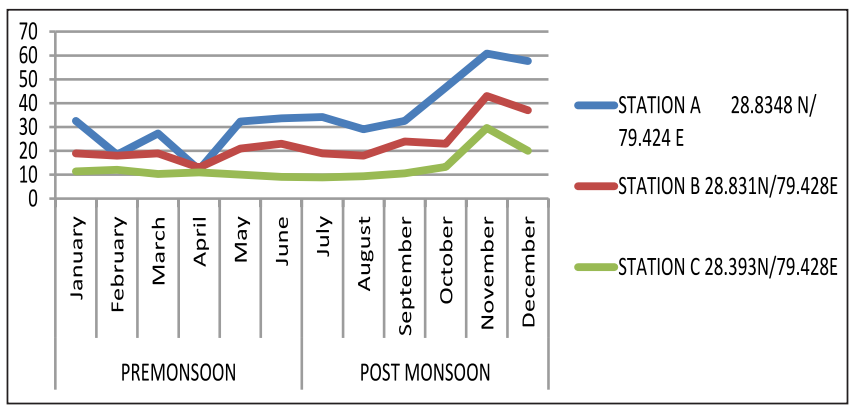

Figure 6: ANNUAL TRENDS (Pre and Post Monsoon) OF $\mathrm{SO}_{2}$ FOR THE YEAR 2019

The gaseous pollutants studied during the course of research was $\mathrm{SO}_{2}$. Bareilly city do not have too much of industrialization. $\mathrm{SO}_{2}$ level were found to be less than the maximum allowable limits [Figure 3] when measured from the three air monitoring sites. For all the stations A, B and C respectively, the post-monsoon average has relatively higher $\mathrm{SO}_{2}$ concentration in comparison to the pre- monsoon average values, and this can be depicted also by the annual average which is significantly higher than the pre-monsoon average. Station A averaged maximum with a value of $34.75 \mu \mathrm{g} / \mathrm{m}^{3}$.

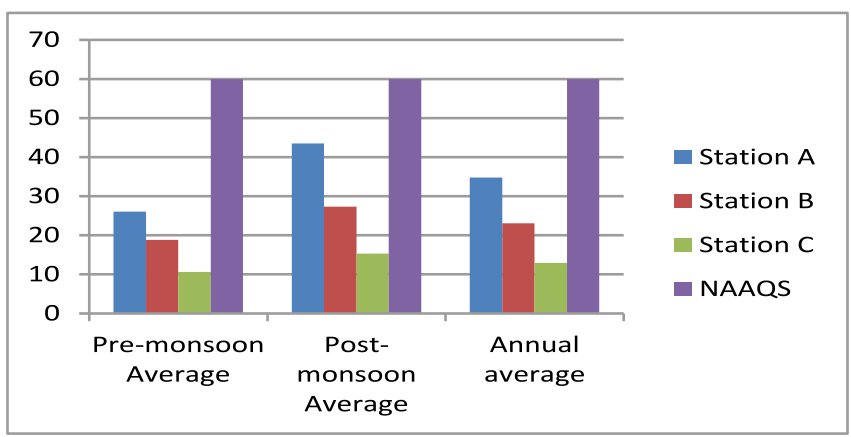

Figure 7: Seasonal and annual Average of SO2 concentrations during 2019. Two way ANOVA test
While conducting the two way ANOVA test for $\mathrm{SO}_{2}$ during both pre-monsoon and post-monsoon seasons from three stations at Bareilly in 2019, it was found that F $>$ F crit. and pvalue $<0.05$ [Table 3] for both seasons and monitoring stations. This signifies that there is significant variation in mean value of gaseous pollutant $\left(\mathrm{SO}_{2}\right)$ during pre and post monsoon season. Also, the three monitoring locations have an appreciable difference in their mean values during pre and post monsoon.

Table 3: Two-way ANOVA for $\mathrm{SO}_{2}$ during the premonsoon and post monsoon season 2019.

\begin{tabular}{|l|c|c|c|}
\hline Source of Variation & F & P-value & F crit \\
\hline Seasons & 12.557189 & 0.0013151 & 4.1708768 \\
\hline Monitoring Stations & 19.159153 & $4.353 \mathrm{E}-06$ & 3.3158295 \\
\hline Interaction & 1.7289299 & 0.1946913 & 3.3158295 \\
\hline
\end{tabular}

\section{Conclusions}

A large number of health issues have been reported which are predominantly due to poor ambient air quality. From the analysis of the gaseous air pollutant $\mathrm{SO}_{2}$ for the year 2019 from three monitoring locations depending on the traffic frequency in the vicinity of $11 \mathrm{~km}$, it can be concluded that the concentration of gaseous air pollutant $\mathrm{SO}_{2}$ in Bareilly city measured from station A were alarming during the winter season and were on the higher side in comparison to the other two stations B and C. Bareilly city do not have too much industrialization and hence emission of gaseous air pollutant sulphur dioxide largely depends on vehicular emissions which is evident from the sale of diesel and petrol fuel reported from the fuel pumps in the study area[26]. As expected, the Station A being a commercial and heavy traffic site showed $\mathrm{SO}_{2}$ relatively higher concentration of $\mathrm{SO}_{2}$ whereas station $\mathrm{C}$ being a residential site recorded much lower $\mathrm{SO}_{2}$ values. Thus, it can be concluded that the possible cause of air pollutant PM2.5 in the city Bareilly could be vehicular emissions. The study carried out for air pollutant analysis is from a limited number of stations covering only an area of $11 \mathrm{~km}$. On increasing the number of monitoring locations better estimate of air quality can be done. Currently, low attention is given to air pollution in spite that millions die due to air pollution all over the world. Air pollution should be thoroughly understood by developing countries and should be given priority. Long-term exposures to gaseous pollutants (up to 24-hours duration) are found to be associated with premature mortality, increased hospital admissions for heart or lung causes, acute and chronic bronchitis, asthma attacks, emergency room visits, respiratory disorders, and restricted activity days. Health of new born babies, children, and older adults with an existing history of heart or lung diseases are found to adversely effected. Health issues due to long-term (months to years) exposure to PM2.5 has been linked to premature death, particularly in patients who already have preexisting chronic heart or lung diseases, and reduced lung function growth in infants. In 2015 a review was published in the International Agency for Research on Cancer (IARC) that concluded that outdoor air pollution causes lung cancer [28]. WHO's IARC[29] have reported exhaust emission, particularly diesel exhaust, as deemed carcinogenic. Nonexhausted emission of traffic-related pollutants, wear out of 
tyre and brakes contributes as much and often more than tailpipe exhaust to the ambient outdoor air pollutants concentrations in cities [27] but no such conclusions have been made in this regard. The increasing level of gaseous pollutants such as $\mathrm{SO}_{2}$ in tir two cities such as Bareilly could be alarming and may pose serious health hazards to the human health.

\section{References}

1. Gurjar, B.R., Butler, T.M., Lawrence, M.G. and Lelieveld, J., Evaluation of emissions and air quality in megacities, Atmospheric Environment, 42, 2008, 1593-1606.

2. Baldasano, J.M., Valera, E. and Jimenez, P., Air quality data from large cities, The Science of the Total Environment, 307, 2003, 141-165.

3. Dubey, B., Pal, A.K. and Singh, G., Assessment of Vehicular Pollution in Dhanbad City Using CALINE 4 Model, International Journal of Geology, Earth and Environmental Sciences, 3, 2013, 156-164.

4. Sharma, N., Chaudhry, K.K. and Rao, C.V.C., Vehicular pollution modelling in India, Journal of the Institution of Engineers (India), 85, 2005, 46-63.

5. Goyal, P., Jaiswal, N., Kumar, A., Dadoo, J.K. \& Dwarakanath, M., Air quality impact assessment of NOx and PM due to diesel vehicles in Delhi, Transportation Research Part D, 15, 2010, 298-303.

6. NEERI Nagpur, Air quality monitoring, emission inventory and source apportionment studies for Delhi, 2008.

7. Sharma, M., Comprehensive Study on Air Pollution and Green House Gases (GHGs) in Delhi, Indian Institute of Technology Kanpur, 2016.

8. Allen, W.R., Davies, H., Cohen, A.M., Mallach, G., Kaufman, D.J., Adar, D.S., The spatial relationship between traffic-generated air pollution and noise in 2 US cities, Environ. Res. 109 (3), 2009, 334-342.

9. Beelen, R., Hoek, G., Houthuijs, D., van den Brandt, P.A., Goldbohm, R.A., Fischer, P., Schouten, L.J., Armstrong, B., Brunekreef, B., The joint association of air pollution and noise from road traffic with cardiovascular mortality in a cohort study, Occup. Environ. Med. 66 (4), 2009, 243-250.

10. Davies, H.W., Vlaanderen, J.J., Henderson, S.B., Brauer, M., Correlation between exposures to noise and air pollution from traffic sources, Occup. Environ. Med. 66 (5), 2009, 347-350.

11. Weber, S. and Litschke, T., Variation of particle concentrations and environmental noise on the urban neighbourhood scale, Atmos. Environ., 42 (30), 2008, 7179-7183.

12. United States Environmental Protection Agency, Risk and Exposure Assessment to Support the Review of the NO2 Primary National Ambient Air Quality Standard, No. EPA-452/R-08-008a, 2008.
13. Crouse, D.L., Goldberg, M.S., Ross, N.A., Chen, H. and Labrèche, F., Postmenopausal breast cancer is associated with exposure to traffic-related air pollution in Montreal, Canada: A case-control study, Environmental Health Perspectives, 118 (11), 2010, 1578-1583.

14. Parent, M.E., Goldberg, M.S., Crouse, D.L., Ross, N.A., Chen, H., Valois, M.F. and Liautaud, A., Trafficrelated air pollution and prostate cancer risk: a casecontrol study in Montreal, Canada, Occupational and Environmental Medicine, 70 (7), 2013, 511-518.

15. Wu, J., Wilhelm, M., Chung, J. and Ritz, B., Comparing exposure assessment methods for trafficrelated air pollution in an adverse pregnancy outcome study, Environmental Research, 111 (5), 2011, 685-692.

16. Weichenthal, S., Farrell, W., Goldberg, M., Joseph, L. and Hatzopoulou, M., Characterizing the impact of traffic and the built environment on near-road ultrafine particle and black carbon concentrations, Environmental Research, 132, 2014, 305-310.

17. Kho, F.W.L., Law, P.L., Ibrahim, S.H. and Sentian, J., Carbon monoxide levels along roadway, International Journal of Environmental Science Technology, 4(1), 2007, 27-34.

18. Nagendra, S.M.S. and Khare, M., Line source emission modelling a review, Atmospheric Environment, 36, 2002, 2083-2098.

19. Venkatram, A. and Horst, T.W., Approximating dispersion from a finite line source, Atmospheric Environment, 40, 2005, 2401-2408.

20. Kenty, K.L., Poor, N.D., Kronmiller, K.G., McClenny, W., King, C., Atkeson, T. and Campbell, S.W., Application of CALINE4 to roadside NO/NO2 transformations, Atmospheric Environment, 41 (20), 2007, 4270-4280.

21. Benson, P. E., A review of the development and application of the CALINE3 and 4 models, Atmospheric Environment Part BUrban Atmosphere, 26 (3), 1992, 379-390.

22. Levitin, J., Härkönen, J., Kukkonen, J. and Nikmo, J., Evaluation of the CALINE4 and CAR-FMI models against measurements near a major road, Atmospheric Environment, 39(25), 2005, 4439-4452.

23. Wallace, J. and Kanaroglou, P., Modeling NOx and NO2 emissions from mobile sources: A case study for Hamilton, Ontario, Canada, Transportation Research Part D: Transport and Environment, 13 (5), 2008, 323-333.

24. Amirjamshidi, G., Mostafa, T.S., Misra, A. and Roorda, M.J. Integrated model for microsimulating vehicle emissions, pollutant dispersion and population exposure, Transportation Research Part D: Transport and Environment, 18(1), 2013, 16-24.

25. Hatzopoulou, M. and Miller, E.J., Linking an activitybased travel demand model with traffic emission and 
dispersion models: Transport's contribution to air pollution in Toronto, Transportation Research Part D: Transport and Environment, 15 (6), 2010, 315-325.

26. Amato, F.; Flemming, R.C.; Denier van der Gon, H.; Gehrig, R.; Gustafsson, M.; Hafner, W.; Harrisson, R.M.; Jozwicka, M.; Kelly, F.J.; Moreno, T.; et al. Urban Air Quality: The Challenge of Traffic NonExhaust Emissions. Available online: http://www.kau.edu.sa/Files/188/Researches/65862_37 290.pdf (accessed on 2 March 2015.).

27. Outdoor Air Pollution IARC Monographs on the Evaluation of Carcinogenic Risks to Humans, Volume 109 IARC.
28. Diesel Engine Exhaust Carcinogenic. Available online: http://www.iarc.fr/en/mediacentre/pr/2012/pdfs/pr213_ E.pdf (accessed on 2 March 2015).].

29. www.cpcb.nic.in

30. IOSR Journal of Environmental Science, Toxicology and Food Technology (IOSR-JESTFT) e-ISSN: 23192402,p- ISSN: 2319-2399.Volume 11, Issue 12 Ver. II (December. 2017), PP 14-29 www.iosrjournals.org.

31. Air Quality Index, ventilation coefficient and pollution potential studies over Bareilly city, Uttar Pradesh. 